\title{
SOCIO-ECOLOGICAL BARRIERS TO ADAPTIVE MANAGEMENT OF LAKE FUQUENE, COLOMBIA
}

\author{
G.I. ANDRADE ${ }^{1,3}$, L. FRANCO ${ }^{2} \&$ J. DELGADO ${ }^{3}$ \\ ${ }^{1}$ School of Management. Universidad de los Andes, Bogotá, Colombia. \\ ${ }^{2}$ Fundación Humedales (Colombian Wetlands Foundation), and PhD Student \\ Universidad Nacional de Colombia, Geography. \\ ${ }^{3}$ Fundación Humedales. Bogotá, Colombia.
}

\begin{abstract}
Lake Fúquene is the most important shallow water body of the tropical northern highland Andes. Five centuries of transformations has changed the natural climatic - pulsing lake - wetland system into a conflicting human-regulated lake and drainage - irrigation district. Management responses are directed toward correction of the consequences of ecological change and affect key structuring variables in the direction of undesired change. Based upon models of ecosystem services and decision-making process, states and trajectory scenarios are proposed. Socio-ecological barriers to sustainable adaptive management were identified. Following the resilience-based approach, a set of biophysical and social attributes were identified to promote a societal agreement around a vision of a multi-functional lake - wetland system. An accurate management agenda is proposed to redirect undesired socio-ecological change to adaptive sustainability.

Keywords: Adaptive management, Colombia, socio-ecological systems, tropical highland lakes.
\end{abstract}

\section{INTRODUCTION}

Lake Fúquene is located in the Colombian Eastern mountain range at $2650 \mathrm{~m}$ altitude (Fig. 1). It is the most important shallow water body of the northern tropical highland Andes. During the second part of the 20th century, the development of a drainage and irrigation district (DID) accelerated the ecological change. Although integrated management goals and biodiversity conservation objectives have been introduced in policy and action plans, management actions seek the continuous optimization of the lake's irrigation services, at the expenses of other ecosystem services. Environmental management still responds to perceived environmental problems that are consequences of the ecological change, and in this way it introduces destabilizing feedbacks on essential variables and accelerates undesired change. Social conflict and public mistrust on environmental authorities are emerging. In this paper we identify the ecosystem services provided by Lake Fúquene and major conflicts between them. Based upon a decision-making process, socio-ecological barriers to sustainable adaptive management were identified and potential commitments for adaptive management are proposed.

\section{LAKE FÚQUENE AS A SOCIO-ECOLOGICAL SYSTEM}

Lakes in northern Andes are small and numerous, and as a result of an active quaternary glacial influence they are found mostly in the higher altitudes. At mid-elevation ranges (1500 to $2500 \mathrm{~m}$ above sea level), the few true lakes occur only in a handful of closed and silted out sedimentary basins, locally known as high flat valleys or altiplanos. Lake Fúquene is one of the few remaining altiplano lakes and as such contains a rich and unique biodiversity. However, since most of the human population in Colombian lives in the mountain regions, these unique ecological systems are under sever human pressure. After the Spanish conquest of the highlands of Colombia, at about 1530, deforestation at Lake Fúquene catchment area started. In 1760, a single large lake covered the valley bottom, and at the end 19th century ecological change scaled-up with extensive draining (Franco [1]). The introduction of the African kikuyu grass (ca. 1930) changed seminatural prairies to managed pastures to sustain dairy industries. While the lake at 1930 still covered $185 \mathrm{~km}^{2}$, the establishment of the 


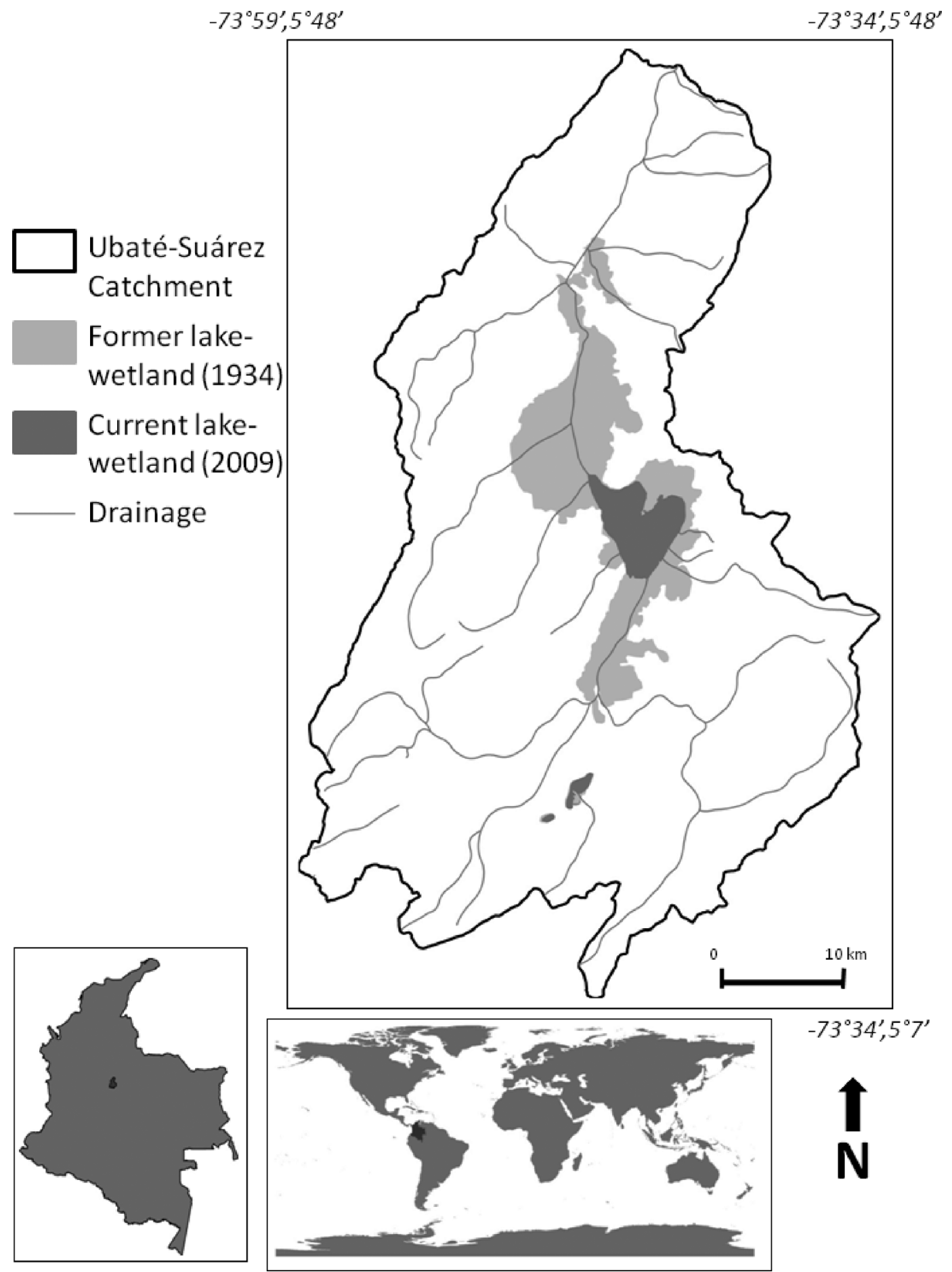

Figure 1: Lake Fúquene catchment area. Light gray former lake - wetland system (1934), and dark gray current lake. 
DID caused the decrease of the lake's water level by average $1 \mathrm{~m}$, and $200 \mathrm{~km}^{2}$ of the bottom of the valley were taken for rising 171,000 cows, supporting 50 dairy facilities. Today, the lake wetland system has been reduced to $31 \mathrm{~km}^{2}$ (Fig. 1). Although under conventional wisdom, Lake Fúquene is seen as a remnant natural ecosystem, according to Walker and Salt [2,] it is considered as a socioecological system (SES) with emerging properties that are the result of biophysical and social interdependencies. Climate and hydrology determines primarily the natural attributes of the SES, manifested in seasonal precipitation patterns, water vegetation processes, infiltration, water quantity and quality, pulse, and circulation patterns within the lake, in the sense given by (Matthews and Le Quesne [3]), Fig. 2.

Five centuries of transformation have produced deep ecological change in the landscape, the most important being the alteration of the water cycle and the transformation of the climatic - pulsing lake - wetland system into a partially regulated lake, although noticeable rainfall variability makes water control inefficient. The dairy landscape lead to a daily input of $48,123 \mathrm{~kg}$ of $\mathrm{N}$ and 6156 of

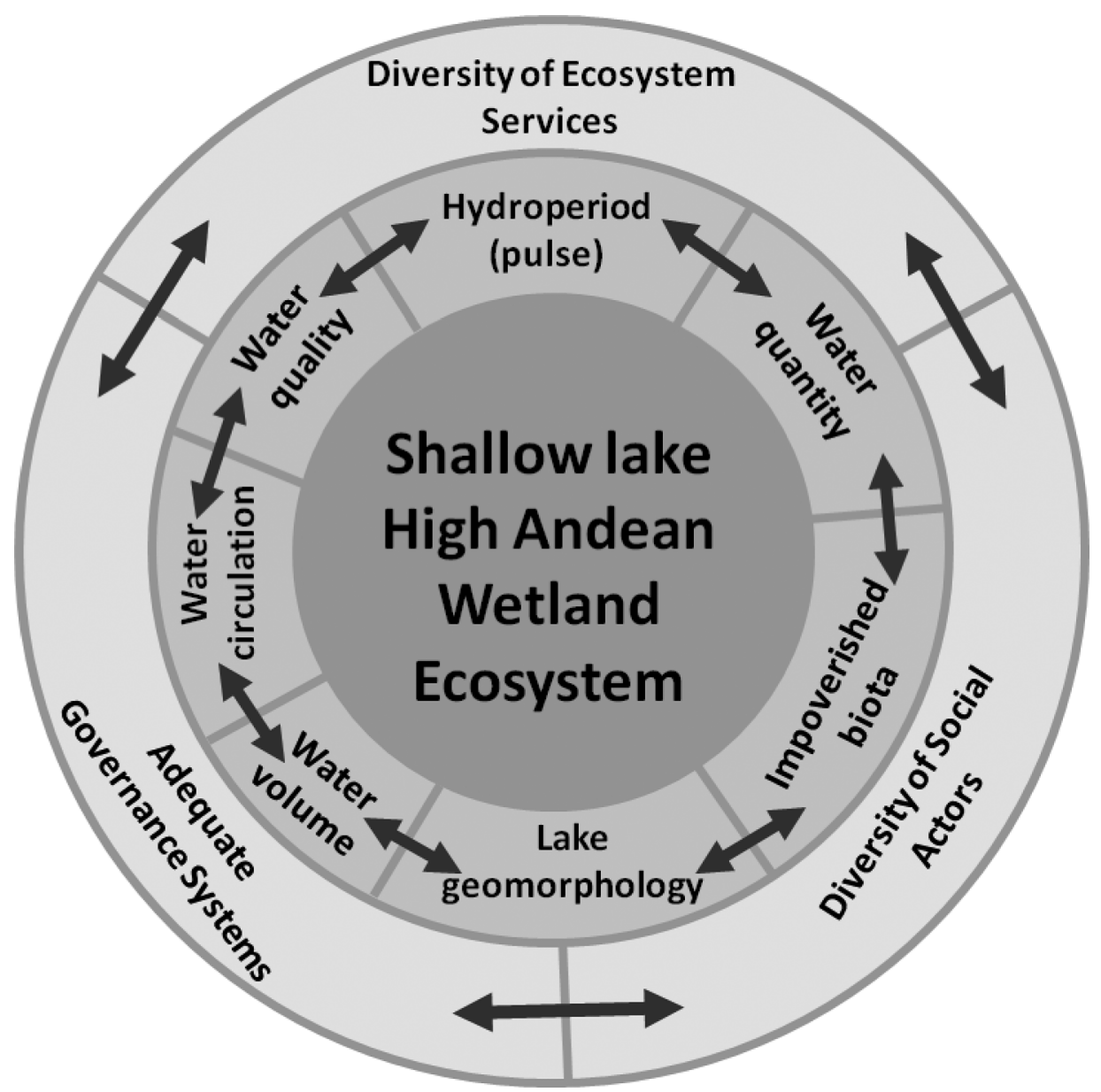

Figure 2: Socio-ecological attributes.

Modified from (Matthews and Le Quesne [3]). 
Phosphorous into the water; the availability of water has also decreased due to interventions at the catchment area, and water inflow decreased between 1960 and 1989 from $3.95 \mathrm{~m}^{3} / \mathrm{s}$ to $2.08 \mathrm{~m}^{3} / \mathrm{s}$ (47\%) [4]. Altogether, these processes modified the ecological structure and functioning of the lake and its ecological character.

Currently, management focuses on stabilizing water fluxes, but regulation is far from optimal. Regular excess waters are evacuated through a peripheral canal built to impede human encroachment and to enhance drainage but actually hampering water circulation exacerbating undesired ecological change within the lake. Levels above $2539.40 \mathrm{~m}$ are considered a flooding risk, and below this level a potential economic loss, since pastures tend to dry up. Seasonality of water availability also determines the system's actual vulnerability to climatic variations and change. During El Niño (2001-2002 and 2009-2010) water shortages were severe in the lowlands and soil toxification occurred leading to great cattle mortality. During 2006, La Niña flooding occurred when the lake attained the 2540.34 $\mathrm{m}$ level, and some dikes failed liberating water over ca. $30 \mathrm{~km}^{2}$ of pastures. The most severe hazard occurred during 2010 La Niña (December), which followed by the regular rainy season in 2011 (April), lead to the failure of some dikes and more than $150 \mathrm{~km}^{2}$ of managed pastures were flooded resulting in the economic collapse of major part of the dairy industries. Limited water availability and insufficient regulation creates a conflict prone scenario, exacerbated by climate variability.

This situation has already kicked back the dairy industry, since many of the pasture lands are literally situated within the former lake - wetland system (Fig. 1). Ecological change across tipping points is reflected in the variations of habitat structure (Fig. 3). Following the model of change by

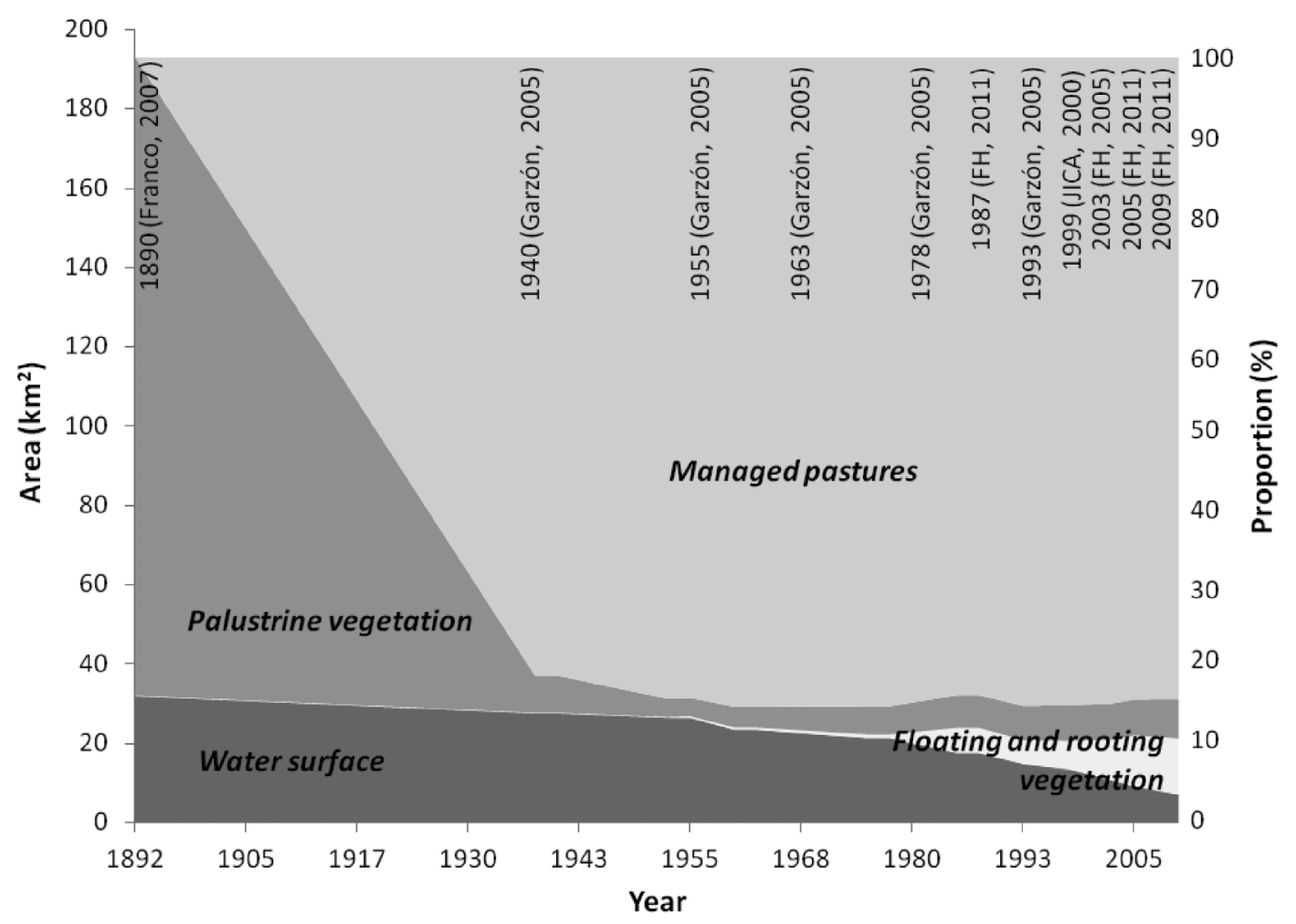

Figure 3: Changes in habitat structure of the Lake from 1892 to 2009. 


\section{Ecosystem state}

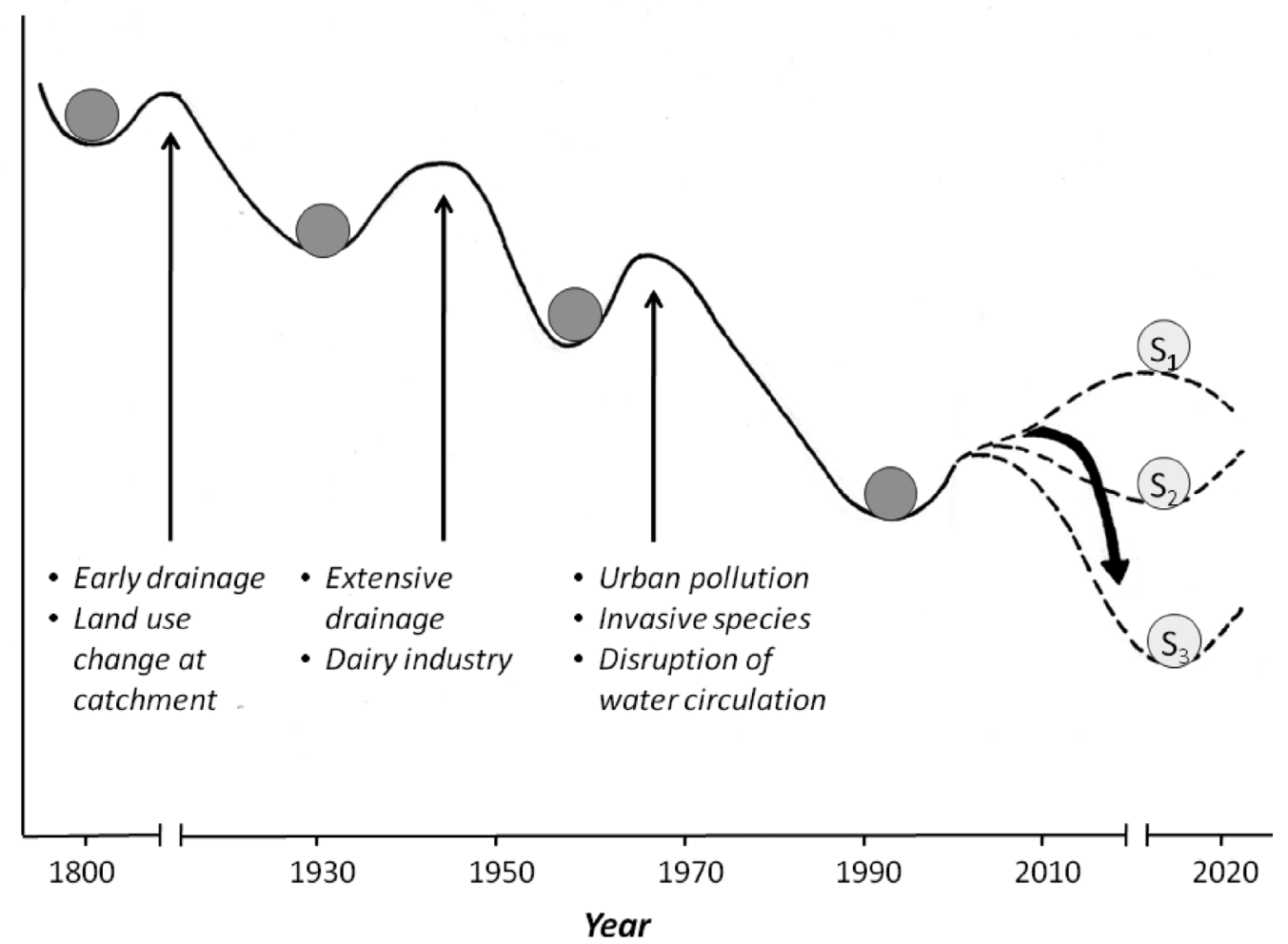

Figure 4: Ecosystem states, trajectories, and management scenarios.

Folke et al. [5], we hypothesize on the states and change trajectory of Fúquene, during the last 200 years (Fig. 4). In the accelerated natural succession, from lake to sedimentary valley, three modified states can be defined. The first followed early drainage and small land use changes at the catchment area, the second as a result of extensive drainage and the development of the dairy industry, and the last following urban and rural pollution, disruption of water cycle and invasion of alien species. Three major management scenarios are foreseen: $S_{1}$ (Fig. 4) is an intensive management and costly reservoir-type scenario, in which socio-ecological surprises might arise, and precipitate the collapse of the system. $S_{2}$ is a proposed multi-functional and stabilized lake wetland model, and $S_{3}$ is the business as usual scenario leading to the stabilization of a terminal degraded wetland state.

\section{IMBALANCE OF ECOSYSTEM SERVICES}

Lake Fúquene provides ecosystem services to society, such as irrigation (10\% agriculture, $90 \%$ dairy industry), fisheries, wildlife habitat, water for human consumption, water regulation, soil nutrient dynamics, and cultural values. Tradeoff scenarios of ecosystem services are presented in Fig. 5, following the general model of representation by Gordon et al. [6] One important current tradeoff is between land uses at the catchment area (agriculture, animal husbandry, and mining) and water regulation processes. At the bottom of the valley, milk production with its concomitant diffuse water 


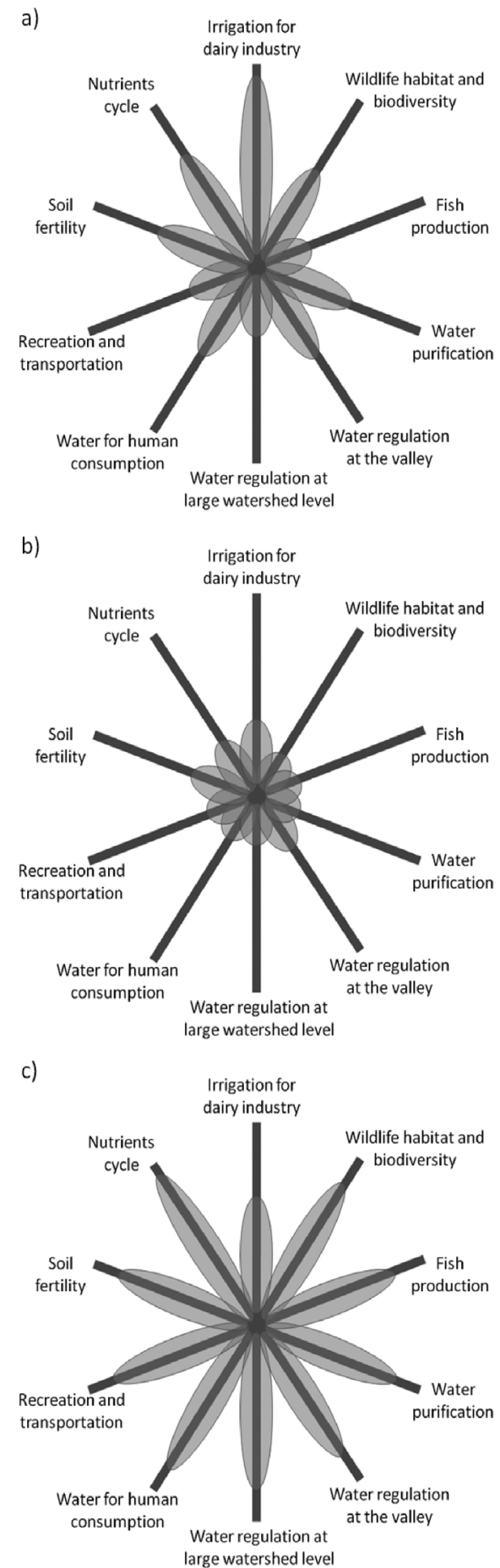

Figure 5: Three ecosystem services scenarios of Lake Fúquene, following Gordon et al. [6]: (a) current, (b) collapse, and (c) proposed (see text for details). 
pollution generates a high cost of water purification. The only legal commitment is that water level must have a minimum of $2539.40 \mathrm{~m}$ to serve the water supply facilities of the of the downstream town of Chiquinquira (46,827 inhabitants). Of great concern for local inhabitants is the collapse of fisheries, directly affecting food security of around 100 families. Reeds that support local handicraft industries are abundant. There is however a concern among artisans about the loss of its quality, which leads them to burn reed beds to make fresh sprouts available. This practice threatens the habitat of resident and migratory birds, and on the long run may feedback habitat degradation. Accelerated succession has, at least temporarily, increased habitat availability for some endangered bird species (reed marsh dwellers).

As a result of human-driven changes, the lake has lost its emblematic value, and cultural ecosystem services, such as transportation and recreation, which due to degradation are not feasible any longer. Currently continued attempts to optimize water irrigation, competes with a stabilizing ecosystem state. Ecological change and conflict are interlinked through functional diversity and social actor strategies, as it has been proposed for forests ecosystems elsewhere in South America by Diaz et al. [7] The ecosystem services scenario is rapidly transiting from maximization of milk production and economic success, at the expense of regulation and supporting services, to the collapse of most of them, reflecting the loss of ecological integrity and the transition across management thresholds.

\section{SOCIO-ECOLOGICAL MISFITS}

The need to understand ecosystem change and to create a communication avenue between scientist, managers, and the population prompted us to identify barriers to sustainable management, based upon the model of socio-ecological misfits proposed by Galaz et al. [8], showing the relationships between decision-making processes, institutional agency and structuring variables and feedbacks (Fig. 6).

The inadequacy of the decision-making process has one major source in the divergence of visions about the lake. Highland peasants feel they live in the 'water production areas', while for them the lake occupies the most productive lands. For cattle ranchers and workers of the dairy industries, the lake - wetland system supports the DID district, although the prevailing management scheme generates risks on dry or wet seasons and years. The shifting baseline syndrome defined by Knowlton and Jackson [9] is illustrated here, since people do not realize the differences between the lake they perceive today as related to the ecological character it had 70 years ago. Riverine peasants culturally attached to the lake see their livelihoods threatened. Among the variety of visions, there is a central institutional misfit. For the institute of rural development (Incoder), the lake is an important site for local community fisheries management. The Colombian Biodiversity Humboldt Institute has declared the lake an Important Bird Area. The Ministry of the Environment and Sustainable Development has yet to recognize the site as a priority wetland within the scope of the Ramsar Convention. For municipal authorities, the claimed lands are sources of revenue through property tax incomes. Within the Regional Autonomous Corporations (RAC) (Spanish acronym CAR), which is the environmental authority, there is a contradictory vision around DID optimization management and environmental control. From 1961 to 1983 RAC received the mandate to manage the DID with drainage functions. Law 99 (1993) integrated RACs to the national environmental system, and by Law 40 DIDs, had to be transferred to its beneficiaries. Despite this decision, and for the direct benefit of local politicians and landowners, the environmental authority RAC has kept DID management functions, generating an annual maintenance cost of ca. 500000 USD/ year [4], a sum that is higher than the whole annual investments for environmental management. Not to mention the increasing budgets allocated for humanitarian relief following 2010-2011 flooding. Local dairy 


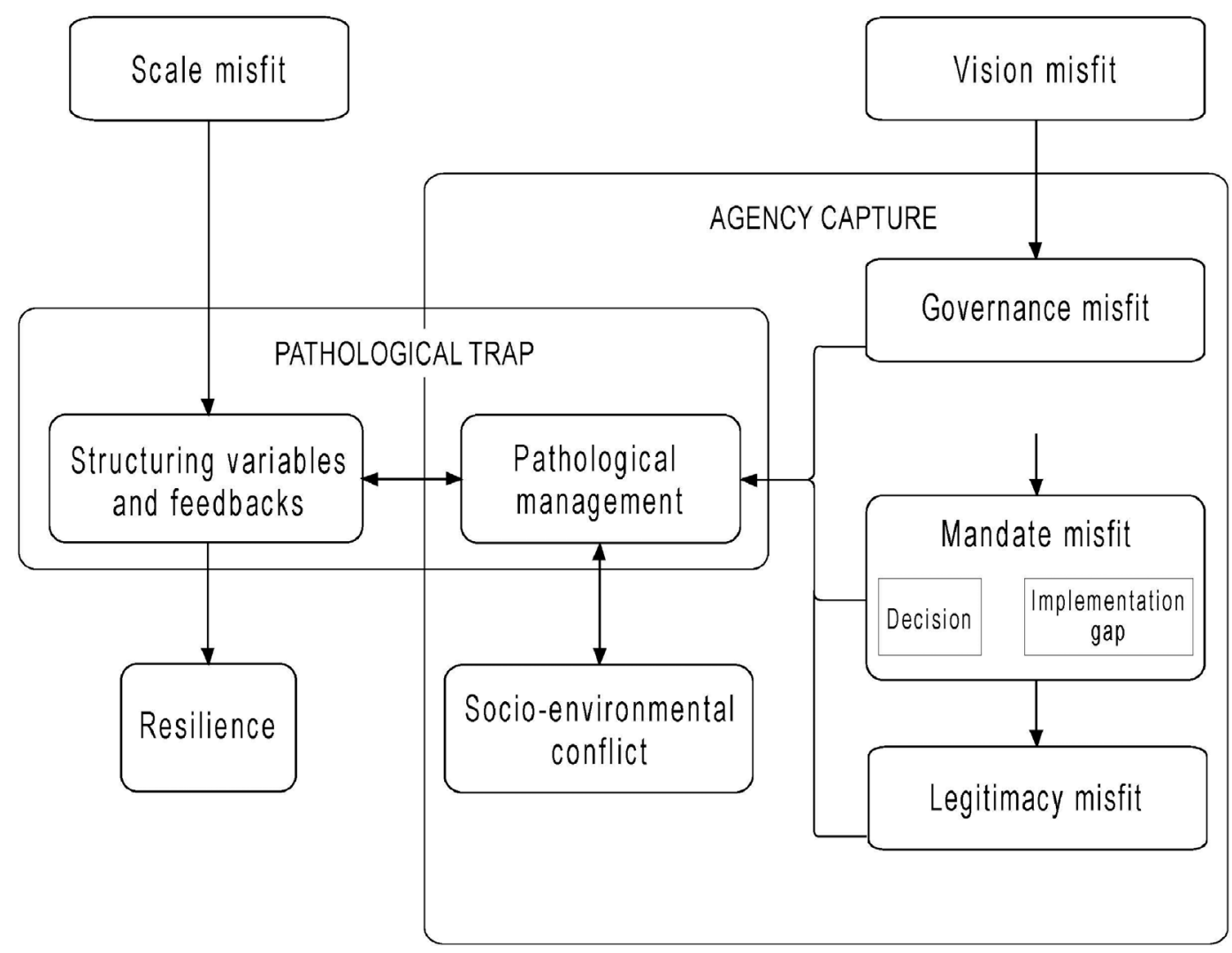

Figure 6: Socio-ecological misfits and unsustainable management processes.

industry has been among the most profited at the country level, something that could partially explained as a result of water subsidies through the scheme of government's management of DID. However, economic losses due to recent flooding are expected to severely affect the finances of the sector. At the catchment area, planning still focuses on schematic opposing land uses rather than ecosystem process and water allocation. Although the environmental flow concept, in the sense proposed by De Dyson et al. [10], has been legally adopted at the country level, locally is yet to be implemented.

Misfits in Lake Fúquene promote to a pathology of management of natural resources, as defined by Holling and Meffe [11]), when the optimization of one service leads to the collapse of the system. The state and trajectory of the system is not a result of an implementation gap (although there are many) but of actual management reflecting the interests of the dairy industry served by public institutions and supported by the population benefiting by the economic activity. However, not all actors' interests are being taken into account, and structuring variables are not recognized as management targets, or are actually managed along undesired trajectories of change. Furthermore, RAC trying to get public support delivers short-term benefits allocating resources for dredging and invasive plants removal, further liberating nutrient into the water and creating destabilizing feedbacks. The undesired situation promotes a legitimacy misfit that is here defined as the lack of congruence between the public institutions and the interest of the society at large. Quite paradoxically, 
although actual management generates winners and losers, there seems to be a general consensus around the inability of RAC to cope with the lake's undesired state and trajectory of change.

\section{IS THERE A WAY OUT FROM PATHOLOGCAL MANAGEMENT?}

Escaping the pathological trap may be possible through resilience-based management [2], which could help overcome the distance between the social mechanism of control and the scale of manifestation of the process. Berkes and Seixas [12] state that freshwater ecosystems are especially adequate for resilience evaluations and adaptive responses. A resilience-based approach requires the recognition of drivers of change and could be used to assess the system's vulnerability to environmental changes. It requires for managers to shift from actions focusing the correction of environmental problems, which are considered in the prevalent management culture as threats, to ecosystem management centered in key structuring variables, and desired trajectories of change. Although there is a great uncertainty as to whether ecological change could be slowed down or redirected, as a policy hypothesis, we propose to move from pathological to adaptive management. Nevertheless, resilience, as an emergent property, cannot be measured or observed; it must be indirectly evidenced through resilience surrogates $\mathrm{R}(\mathrm{S})$, as proposed by Bennet et al. [13] RS are biophysical attributes linked with the lake's desired socio-ecological character and should be testable against the resilience theory and the ecological integrity of the ecosystem and be formulated from a management perspective. RS surrogates for Lake Fúquene are being defined by Franco et al. [14] to propose an accurate management agenda focusing those attributes that can be modified by management to redirect the system's trajectory of change toward adaptation.

An important step forward would be to have a transparent definition of the key variables, which could be made explicit with RS to be targeted through management. Follow-up on the state of indicators would bring the knowledge base for an adaptive governance management, including international stakeholders. At the field level, actions that create positive destabilizing feedbacks should cease and be replaced by attempt to redirect the system to a state containing the values of a multiple functional lake - wetland system. This would help society spare time and keep options alive for an adaptive transformation process, as climate variations have the potential to further modify the trajectories of change of water-dependent high Andean ecosystems [15] and socio-economic activities.

\section{ACKNOWLEDGMENTS}

Research work was possible through the general financial support of Fundación Humedales (Colombian wetlands foundation) Ecopetrol, the Alexander von Humboldt Biodiversity Research Institute, the Global Nature Fund (Germany), and the International Living Lakes Network. Mario Hernandez, Sandra Hernandez and Jairo Valderrama supported field work and gave valuable information. The community-based organization Association Los Fundadores generously participated in field research and discussion activities.

\section{REFERENCES}

[1] Franco, R. Elementos para una historia ambiental de la región de la laguna de Fúquene en Cundinamarca y Boyacá. Fúquene, Cucunubá y Palacio. Conservación de la biodiversidad y manejo sostenible de un ecosistema lagunar andino. Fundación Humedales e Instituto de Investigación de Recursos Biológicos Alexander von Humboldt. eds En. Franco, L \& G. I. Andrade.Bogota. Colombia, 2007.

[2] Walker, B. \& D. Salt. Resilience Thinking. Sustaining Ecosystems and People in a Changing World. Washington, DC: Island Press, 2006. 
[3] Matthews, J. \& T. Le Quesne. Adapting Water Management: A Primer on Coping with Climate Change Report. Vol. 3. Godalming: WWF-UK, 2009.

[4] Useche, F. CONPES de Fúquene: Estrategia para el manejo ambiental de la cuenca Ubaté Suárez. Carta Ambiental (CAR) 12, pp. 12-16, 2007.

[5] Folke, C., Chapin, F.S., III \& Olsson, P. Transformations in Ecosystem Stewardship, Principles of Ecosystem Stewarship, 399. eds En: Chapin et al., Springer Science. pp. 103-125, 2009. ISBN: 978-0-387-73032-5.

[6] Gordon, L., C. Finlayson \& M. Falkenmark. Managing water in agriculture for food production and other ecosystem services. Agricultural Water Management, 97, pp. 512-519, 2010. doi: http://dx.doi.org/10.1016/j.agwat.2009.03.017

[7] Díaz, S., Quétier, F., Cáceres, D.M., Trainor, S.F., Pérez-Harguindeguy, N. Syndonia Bret-Harte, M., Finetan, B., Marieslos Panna-claros, \& Poorter, L. Linking functional diversity and social actor strategies in a framework for interdisciplinary analysis of nature's benefits to society. PNAS, 18(108): 895-902, 2011.

[8] Galaz, V., Olson, P. Hahn, T. Folke, C. \& Svedin, U. The problem of fit between ecosystems and governance systems: insights and emerging challenges. The Institutional Dimensions of Global Environmental Change: Principal Findings and Future Directions, eds O. Young, L.A. King \& H. Schroeder, Boston, Ma, USA: MIT Press, 2008.

[9] Knowlton, N. \& J.B.C. Jackson. 2008. Shifting baselines, local impacts, and global change on coral reefs. PLoS Biol, 6(2): e54. doi:10.1371/journal. pbio.0060054.

[10] De Dyson, M., Bergkamp, G., Scanlon, J (eds.). 2003 The Essentials of Environmental Flows. IUCN, Gland, Switzerland and Cambridge UK.

[11] Holling, C.S. \& Meffe, G.K. Command and Control and the Pathology of Natural Resource Management. Conservation Biology, 10(2), pp. 328-337, 1995. doi: http://dx.doi.org/10.1046/ j.1523-1739.1996.10020328.x

[12] Berkes, F. \& Seixas, C. Building Resilience in Lagoon Social - Ecological Systems: A Local-level Perspective. Ecosystems, 8, pp. 967-974, 2005. doi: http://dx.doi.org/10.1007/ $\underline{\text { s10021-005-0140-4 }}$

[13] Bennett, E.M., Cumming, G.S. \& Peterson, G.D. A systems model approach to determining resilience surrogates for case studies. Ecosystems, 8, 945-957, 2005. doi: http://dx.doi. org/10.1007/s10021-005-0141-3

[14] Franco, L., Delgado, J. \& Andrade, G. Presentation at Resilience 2011. Second International Science and Policy Conference. Tempe Arizona: Arizona State University, 2011.

[15] Poveda, G., Alvarez, D.M. \& Rueda, O.A. Hydro-climatic variability over the Andes of Colombia associated with ENSO: A review of climatic processes and their impact on one of the Earth's most important biodiversity hotspots. Clim Dyn 35(6), pp. 2233-2249, 2010. online DOI 10.1007/s00382-010-0931-y. 